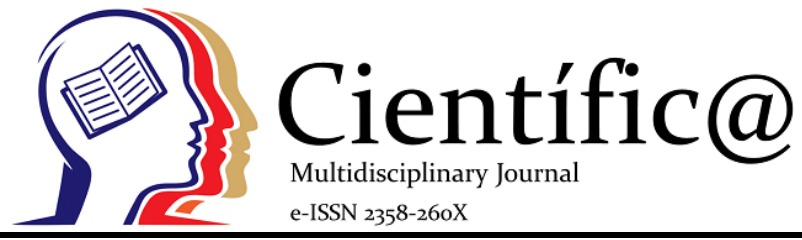

\title{
Efficiency Of A Sewage Treatment Station In The Elimination Of Fecal Contaminations
}

\author{
Eficiência De Uma Estação De Tratamento De Esgoto Na Eliminação Da Contaminação Fecal \\ Luiz Carlos Leonel Martins ${ }^{1}$, Debora Cabral Machado ${ }^{1}$, Victor Hugo Moraes ${ }^{2 *}$, Matheus \\ Vinicius Abadia Ventura ${ }^{2}$, Germanna Gouveia Tavares ${ }^{2}$ \& Lorena Cristina Alves Nogueira ${ }^{2}$ \\ ${ }^{1}$ UniRv- Universidade de Rio Verde Campus Rio Verde \\ ${ }^{2}$ Instituto Federal Goiano Campus Rio Verde; victor.cm1@hotmail.com
}

Info

Recebido: $24 / 01 / 2019$

Publicado: $31 / 05 / 2019$

DOI: 10.29247/2358-260X.2019v6i1.p49-54

ISSN: 2358-260X

Palavras-Chave

Coliformes; Efluente; Termotolerantes

Keywords:

Coliformes; Effluent; Thermotolerant

\section{Abstract}

Sewage from the various water uses such as domestic and industrial uses, as well as a high content of organic matter may contain chemical, toxic and pathogenic microorganisms. The present study was developed at the Sewage Treatment Station (ETE) in the municipality of Santa Helena de Goiás - Goiás and had as objective to evaluate the efficiency of the sewage treatment process in the elimination of fecal microbial contamination regarding the level of thermotolerant coliforms . Samples were collected in the months of March, April, May and June, which corresponded, respectively, to the rainy and dry season. The samples collected at the arrival of the raw sewage, in the final emissary, source spring being upstream and upstream were conditioned at $4^{\circ} \mathrm{C}$ until the moment of the analysis; the Most Probable Number (NMP) or multiple tubes technique was used. It was verified that the ETE reached a significant efficiency index in the elimination of fecal coliforms, and in the period of rain there was a reduction of $99.8 \%$ and in the period of the drought a reduction of $99.7 \%$ in the fecal contamination after the treatment of sewage.

\section{Resumo}

Os esgotos provenientes dos diversos usos da água tais como as de uso domésticos e industriais, além de um elevado teor de matéria orgânica podem conter em sua composição substâncias químicas, tóxicas e microrganismos patogênicos. 0 presente estudo foi desenvolvido na Estação de Tratamento de Esgoto (ETE) do município de Santa Helena de Goiás - Goiás e teve como objetivo avaliar a eficiência do processo de tratamento de esgoto na eliminação da contaminação microbiana de origem fecal quanto ao nível de coliformes termotolerantes. Foram coletadas amostras nos meses de março, abril, maio e junho que correspondiam, respectivamente, ao período de chuva e de seca. As amostras coletadas na chegada do esgoto bruto, no emissário final, manancial receptor sendo na jusante e montante foram acondicionadas a $4^{\circ} \mathrm{C}$ até o momento da análise; foi utilizada a técnica do Número Mais Provável (NMP) ou dos tubos múltiplos. Constatou-se que a ETE atingiu um índice de eficiência significativo na eliminação de coliformes fecais, sendo que, no período de chuva houve uma redução de 99,8\% e no período da seca uma redução de $99,7 \%$ na contaminação fecal após o tratamento do esgoto. 


\section{INTRODUCTION}

The municipality of Santa Helena de Goias is located in the southwest of the state of Goias, occupies an area of 1,127,855 $\mathrm{km}^{2}$ and has a population of 38,743 inhabitants (IBGE, 2018). It is a municipality that goes through a process of population and industrial expansion. The capital mainly revolves around agriculture and industrial centers such as Italac, Santa Helena sugar and alcohol mill, Monsanto do Brasil and also a Hering company.

Much of the water distributed in city buildings becomes sewage, so they must be collected and treated before being dumped into soils or bodies of water. The different types of sewage have several characteristics, varying according to the type of water use, such as: hospital, industrial and domestic sewage (FONTES; ARAÚJO, 2008). Sewage can be classified into two categories: domestic sewage from household sewage and trade, and the other as industrial sewage that originates from small or large industries and requires a pretreatment prior to its arrival in sewage treatment station (BASTOS, 1999).

Water is a substance essential to the survival of all living things. To be considered drinkable for humans, it must have physicalchemical and microbiological characteristics that do not endanger the health of the consumer. According to Brazilian legislation, potable water can not contain any thermotolerant (fecal) coliform in $100 \mathrm{~mL}$ of analyzed sample (BRASIL, 2006). To achieve this standard the water must originate from uncontaminated source or contaminated water must be submitted to a treatment that eliminates the fecal contamination present.

Borges et al. (2003) evaluated the water quality of the "Cerradinho and Jaboticabal" streams after the installation of sewage interceptors in an urban area, and the authors commented that, although the interceptors implantation was not sufficient to decontaminate the waters of the streams, the intensity of the pollution decreased. In addition to poor hygienic-sanitary quality, the presence of thermotolerant coliforms in the water indicates the possibility of the presence of pathogenic micro-organisms, alerting to the danger of transmission and dissemination of diseases transmitted by water and contaminated food during its production (JAY, 2005). Franco et al. (2007) have shown great concern for the water from the Três Barras stream watershed in Marinopolis, São Paulo, used for the irrigation of vegetables, due to the detection of a large number of thermotolerant coliforms at one of the collection points.

Thermotolerant coliforms were also found at levels above that tolerated in vegetables and irrigation water from vegetable gardens in the city of Ribeirao Preto - São Paulo (TAKAYANAGUI et al., 2007). Camargo e Paulosso (2009) evaluated the microbiological quality of water wells from Carlinda - Mato Grosso, consumed by the population of one of the boroughs of the municipality and concluded that the high incidence of thermotolerant coliforms and Escherichia coli 
fecal bacteria in the samples could be explained by the small distance between the wells and the septic tanks, since the neighborhood did not have a sewage system.

The objective of this study was to evaluate the efficiency of the sewage treatment process in the elimination of fecal microbial contamination in effluents carried out by the sewage treatment plant of the municipality of Santa Helena de Goias in the year 2017 and to compare the quantity of thermotolerant coliforms found in the samples with the current legal standards determined by the National Council of the Environment (CONAMA, 2018).

\section{MATERIAL AND METHODS}

The samples were collected at four points of the sewage treatment plant in the months of March and April (rainy season), May and June (dry period), being: raw sewage (parshall gutter), final effluent, downstream and source of the effluent. Each collection point for each period was sampled three times, totaling 24 samples.

Three samples were collected at each collection point with an interval of five minutes each in the morning period. The samples were packed in a polyethylene bottle and kept at $4^{\circ} \mathrm{C}$. The temperature was confirmed with the thermometer in an icebox until the time of analysis. Each sample was accompanied by a technical file with the following information: day, time, place, room temperature and sample, sample collector and interested in the analysis.
Microbiological analyzes of the samples were performed using the Most Probable Number (MPN) or multiple tube (SILVA et al., 2005), and the research and enumeration of thermotolerant coliforms in the sample. At the stage of sample processing and preparation of the serial dilutions, after sample homogenization $\left(180^{\circ} / 25 \mathrm{X}\right.$ movement), $1 \mathrm{~mL}$ was withdrawn and transferred to a tube with $9 \mathrm{~mL}$ of $0.9 \%$ saline solution to obtain dilution $10^{-1}$. One milliliter of the dilution $10^{-1}$ was taken to obtain the dilution $10^{-2}$ and to obtain the dilution $10^{-3}$.

To detect the presence of coliforms (presentive test) used $1 \mathrm{~mL}$ for each sample, mading 3 dilution of each, that was transferred to 3 tubes with $10 \mathrm{~mL}$ of lactose broth and Durhan tube. After inoculation the tubes were incubated at $35^{\circ} \mathrm{C}$ for a period of 24 to $48 \mathrm{~h}$ in a growing greenhouse. In the confirmatory test, from the tubes of the presumptive test that presented gas bubbles $\left(\mathrm{CO}_{2}\right)$ inside the tubes of Durham (positive result), elevations were withdrawn that were inoculated, respectively, in tube with $10 \mathrm{~mL}$ of EC broth, for the confirmation of the presence of thermotolerant coliforms. The tubes with EC broth were incubated at $44.5^{\circ} \mathrm{C}$ for $24 \mathrm{~h}$.

To determine the most probable number of thermotolerant coliforms $/ \mathrm{mL}$ of the sample, the number of EC broth tubes showing gas bubbles $\left(\mathrm{CO}_{2}\right)$ in Durham tubes (positive result) was used to enumerate the population of thermotolerant coliforms through the table of NMP. 


\section{RESULTS}

Tables 1 and 2 show the results of the microbiological analyzes of the samples.

TABLE 1: Most probable number (MPN) of fecal coliforms in the samples collected in the rainy season.

\begin{tabular}{clcc}
\hline Sample & Max value MPN/mL & Mean value $\mathbf{M P N} / \mathbf{m L}$ & Min value $\mathbf{M P N} / \mathbf{m L}$ \\
\hline Raw sewage & $>3000$ & $>2.400$ & $>2000$ \\
Final sender & 9 & 5 & 6 \\
Amount & 5 & 5,6 & 4 \\
Downstream & 7 & 3 & 5 \\
\hline
\end{tabular}

Data analysis showed that there was a According to CONAMA resolution 20/86 and difference between the number of fecal coliforms $274 / 2000$, which defines the criteria for bathing in in the raw sewage and treated sewage samples, both Brazilian waters, the waters required for recreation in the rainy season and in the dry season. of primary contact must follow the classifications.

TABLE 2: Most probable number (MPN) of fecal coliforms in the samples collected during the dry season.

\begin{tabular}{lccc}
\hline Sample & $\begin{array}{l}\text { Max value MPN/mL } \\
\text { MPN/mL }\end{array}$ & Mean value MPN/mL & Min value \\
\hline Raw sewage & $>3000$ & $>2.400$ & $>2000$ \\
Final sender & 9 & 7,3 & 6 \\
Amount & 5 & 4,6 & 4 \\
Downstream & 7 & 5,6 & 5 \\
\hline
\end{tabular}

According to Tables 1 and 2, the water quality of the source of the treated sewage falls within the norms established by CONAMA. The quality of the spring water, after having received the treated sewage can be classified as excellent for recreational activities.

Based on the conditions analyzed, the results allowed to conclude that the sewage treatment plant of the municipality of Santa Helena de Goias was efficient in reducing fecal contamination mainly during the rainy season. Thus, the effluent released in the spring did not interfere directly in the water quality of the same, making it suitable for bathing.

\section{DISCUSSION}

The sewage treatment station achieved a significant efficiency index in the elimination of fecal coliforms, and in the rainy period there was a reduction of $99.8 \%$ and in the period of drought a reduction of $99.7 \%$ in fecal contamination after the treatment of sewage, in the rainy has a better result because the water of the rain made the diluation of the fecal coliforms. The data found in this study 
coincided with the data obtained by Fontes e Araújo (2008), where they concluded that there was a $97.5 \%$ to $99.98 \%$ reduction in the number of fecal coliforms after sewage treatment, the authors argued that although there was a high efficiency in the reduction of fecal contamination, the values found at the time of discharge effluent were found to be higher than the values found in the amount of sewage treatment station.

Vasconcelos et al. (2002) evaluated the water quality of Ribeirao Meia Ponte and Ribeirão Joao Leite and verified the commitment caused to these springs by the activities developed in the region. The quality of the two bodies of water in the condition of sources of supply was compared. The results showed lower levels of organic matter and better bacteriological quality in the Joao Leite stream than in Ribeirao Meia Ponte.

Machado and Santos (2000) made an evaluation of the level of water contamination in a lotic system of brazilian savannas and its relationship with some abiotic factors. According to the authors, the fluctuations of the level of contamination in the catchment of Ribeirao João Leite were significant, showing a compromise of the bacteriological quality, with fecal coliforms being the variable with more effect of magnitude in the prediction of total coliforms.

Souza et al. (1983) evaluated the total and fecal coliforms index in waters used in the watering of animals; 105 water samples were collected, 44 of water sources and 61 of drinking fountains, although there were no bacteriological parameters for drinking fountains, only $6(9.8 \%)$ of the 61 samples studied could not be used for animal watering. source of the STS effluent must be within the legal parameters so that it does not reach the quality of life of the animals. Buzelli and CunhaSantino (2013), the average of fecal coliforms collected in the reservoir was, respectively, $50 \mathrm{CFU}$ (colony forming units)/100 $\mathrm{mL}$ and in the rainy season: $3800 \mathrm{CFU} / 100 \mathrm{~mL}$.

\section{CONCLUSIONS}

According to CONAMA 357/2005, it defines the drought period as Class 1 and the rainy season as Class 3, with a concentration of more than $2500 \mathrm{CFU} / 100 \mathrm{~mL}$ being considered improper, demonstrating that the Barra Bonita reservoir is considered excellent in the dry season and improper in the rains.

\section{REFERENCES}

BASTOS, RKX. Fertirrigação com águas residuárias. In: FOLEGATTI, MV (Coord.). Fertirrigação: citrus, flores e hortaliças. Guaíba: Agropecuária, 1999.

BRASIL. Vigilância e controle da qualidade da água para consumo humano. Brasília: Ministério da Saúde, 2006.

BORGES, MJ.; GALBIATTI, JA.; FERRAUDO, AS. Monitoramento da qualidade hídrica e eficiência de interceptores de esgoto em cursos de água urbanos da bacia hidrográfica do córrego Jaboticabal. Revista Brasileira de Recursos Hídricos, Belo Horizonte, 2003; 8:161-171.

BUZELLI, GM.; CUNHA-SANTINO, MB. Análise e diagnóstico da qualidade da água e estado trófico do reservatório de Barra Bonita, SP. Ambiente \& Água - An 
Interdisciplinary Journal of Applied Science, 2013; 8:186-205.

CAMARGO, MF.; PAUlOSSO, LV. Avaliação qualitativa da contaminação microbiológica das águas de poços no município de Carlinda - MT. Seminário de Ciências Biológicas e da Saúde, 2009; 30:77-82.

CONAMA - Conselho Nacional do Meio Ambiente. 2018. Disponível em $<$ http://www.mma.gov.br/port/conama/ >. Acesso em: 18 agosto 2018.

FRANCO, RAM.; HERNANDEZ, FBT.; VANZELA, LS. Utilização dos parâmetros coliformes totais e fecais e oxigênio dissolvido na avaliação da qualidade de água para irrigação na microbacia do córrego Três Barras. In: CONGRESSO BRASILEIRO DE ENGENHARIA AGRÍCOLA, XXXVI, 2007, Bonito. Resumos... Bonito: AGROLINK, 2007. Disponível em $<\mathrm{ftp}: / / \mathrm{ftp}$.feis.unesp.br/agr/pdf/conbea20 07_coliformes_tres_barras.pdf $>$.

FONTES, IBM.; ARAÚJO, QR. Eficiência na remoção de coliformes na estação de tratamento de esgoto de Ilhéus (Bahia). Geografia, 2008; 17:127-136.

IBGE - INSTITUTO BRASILEIRO DE GEOGRAFIA E ESTATÍSTICA. Cidades $2018 . \quad$ Disponível em $<$ http://cidades.ibge.gov.br/xtras/perfil.ph p?codmun $=521930>$. Acesso em 18 agosto 2018.

JAY, JM. Microbiologia de alimentos. 6 ed. Porto Alegre: Artmed, 2005.

MACHADO, L de SM.; SANTOS, CRA. dos. Avaliação do nível de contaminação da água em um sistema lótico de cerrado e sua relação com alguns fatores abióticos. In: CONGRESSO INTERAMERICANO DE ENGENHARIA SANITÁRIA E AMBIENTAL, XXVII, 2000, Campinas. Resumos... Campinas: ABES, 2000. Disponível em <www.bvsde.paho.org>. Acesso em: 18 agosto 2018.

SILVA, N.; CANTÚSIO NETO, R.; JUNQUEIRA, VCA.; SILVEIRA, NFA. Manual de métodos de análise microbiológica da água. 1 ed. São Paulo: Varela, 2005.

SOUZA, LC.; IARIA, ST.; PAIM, GV.; LOPES, CAM. Bactérias coliformes totais e coliformes de origem fecal em águas usadas na dessedentação de animais. Revista de Saúde Pública, 1983; 17: 112-122.

TAKAYANAGUI, OM.; CAPUANO, DM.; OLIVEIRA, CAD.; BERGAMINI, AMM.; OKINO, M HT.; CASTRO e SILVA, AAM. C.; OLIVEIRA, MA.; RIBEIRO, EGA.; TAKAYANAGUI, AMM A. Avaliação da contaminação de hortas produtoras de verduras após a implantação do sistema de fiscalização em Ribeirão Preto, SP. Revista da Sociedade Brasileira de Medicina Tropical, 2007; 40: 239-241.

VASCONCELOS, SMS.; SERAFINI, BA.; SANTOS, CRA; MARQUES, RG. Relação da ocorrência de coliformes totais e fecais com parâmetros físico-químicos de controle de qualidade da água no rio Meia Ponte e Ribeirão João Leite (Goias - Brasil). In: CONGRESSO INTERAMERICANO DE ENGENHARIA SANITÁRIA E AMBIENTAL, XXVIII, 2002, Cancun. Resumos... Cancun: ABES, 2002. Versão eletrônica. 